\title{
THE IMPACT OF BI INTEREST RATE AND AMOUNT OF MONEY ON INFLATION IN INDONESIA DURING 2017-2019
}

\author{
Putri Sari MJ Silaban \\ Economic Education Study Program, State University of Medan \\ Email:ellonagultom01@gmail.com \\ Dita Natania Harefa \\ Economic Education Study Program, State University of Medan \\ Email: ditanatania88@gmail.com \\ Januarti Ira Melenia Napitupulu \\ Economic Education Study Program, State University of Medan \\ Email: melenianapitupulu@gmail.com \\ Jessica Putri Br. Sembiring \\ Economic Education Study Program, State University of Medan \\ Email: jessicasembiring76@gmail.com
}

Received: August 2020; Accepted: November 2020; Available online: January 2021

\begin{abstract}
The economic progress of a country is surely influenced by its economic indicators. This indicator is an important thing to pay it attention. One of the economic indicators is inflation. Inflation will affect the economy aggregately. Due to the increase in inflation and inflation instability, it will indicate that the level of prices for goods and services in a country is high. In the end, this will have an impact on people's interest in buying these goods or using these services. Of course, the large impact will be sustainable on national income. Therefore, this study aims to analyze the effect of interest rates and the money supply on inflation in Indonesia in 2017-2019. The types of data used in this study are quantitative data and the data sources used are taken from BPS for the 2017-2019 period. .The final result of this study showed that based on the results of the analysis, it could be concluded that interest rates and the amount of money have an impact on inflation with a significance value of 0.000296 . Meanwhile, the t-test results indicate that interest rates and the money supply have an impact on inflation, respectively, with values of significance are 0.0371 and 0.0286 .
\end{abstract}

Keywords: Inflation; interest rates; the money supply; Indonesian income.

\begin{abstract}
Abstrak
Kemajuan ekonomi suatu negara tentunya dipengaruhi oleh indikator perekonomiannya .Indikator ini merupakan suatu hal yang penting untuk diperhatikan. Salah satu indikator perekonomian tersebut adalah inflasi.Inflasi akan mempengaruhi perekonomian secara agregat. Dikarenakan kenaikan inflasi dan tidak stabilnya inflasi akan menandakan bahwa tingkat harga barang dan jasa di suatu negara itu tinggi. Akhirnya ini akan berdampak terhadap minat masyrakat untuk membeli barang atau menggunakan jasa tersebut.Tentunya, dampak besarnya akan berkelanjutan terhadap pendapatn nasional. Oleh karena itu, penelitian ini memiliki tujuan untuk menganalisis pengaruh suku bunga dan jumlah uang beredar terhadap inflasi di Indonesia pada tahun 2017-2019.Adapun jenis data yang digunakan dalam penelitian ini adalah data kuantitatif dan sumber data yang digunakan diambil dari BPS periode 2017-2019. Hasil akhir dari penelitian ini menujukkan bahwa berdasarkan hasil analisis dapat ditarik kesimpulan bahwa suku bunga dan jumlah uang beredar berpengaruh terhadap inflasi dengan nilai signifikansi sebesar 0,000296. Sedangkan
\end{abstract}


dari hasil uji t diperoleh hasil bahwa suku bunga dan jumlah uang beredar berpengaruh terhadap inflasi masing masing dengan nilai signifikansi sebesar 0,0371 dan 0,0286.

Kata kunci: Inflasi; suku bunga; jumlah uang beredar; perekonomian Indonesia.

How to Cite: Silaban, P. S. M. J., Harefa, D. N., Napitupulu, J. I. M. \& Sembiring, J. P. Br. (2021). The Impact of BI Interest Rate and Amount of Money Supply on Inflation in Indonesia During 2017-2019. Media Ekonomi dan Manajemen, 36(1), 62-75. doi: http://dx.doi.org/ 10.24856/mem.v36i1.1636.

\section{INTRODUCTION}

Inflation has an important role in the 'trade-off' of the economy so that economy in a country remains and continues to grow. A growing economy shows a stretching market where economic activity in every line of society keeps moving. As long as inflation is still within normal levels, meaning that it is not too high or low, economic stability will be maintained. Developing countries generally have an economic structure that is still in an agrarian pattern, which tends to be very vulnerable of shocks to the stability of economic activity. In a country such as Indonesia, turmoil often occurs in terms of keep the stability of economic activity. Being the most important concern,make economy problems need to be more attentionto overcome it because if the economy is in an unstable condition, economic problems will arise such as low economic growth, high unemployment rate and high inflation rate. We can use economic growth to see and make it as a measure of the stability of economic, there is no high unemployment rate and the level of prices for goods and services whose changes are insignificant as reflected in the inflation rate. One of the important economic indicators is inflation, its rate change is always expected to be low and stable in order to not to create macroeconomic diseases which will later have instability impact in the economy (Langi, Masinabow \& Siwu, 2014).

Based on Figure 1, it can be seen that the development of inflation during period of 2017-2019 had various fluctuations. The highest inflation occurred in June 2017 at $4.37 \%$ then moved down in
November 2017 at $3.30 \%$. In its development every year, the lowest inflation was obtained in March 2019 at $2.48 \%$ but then increased in September 2019 at $3.39 \%$ and then decreased in December 2019 at $2.72 \%$.

Figure 1. Indonesia's Inflation in 2017-2019

Source: Bank Indonesia research data (processed in 2020)

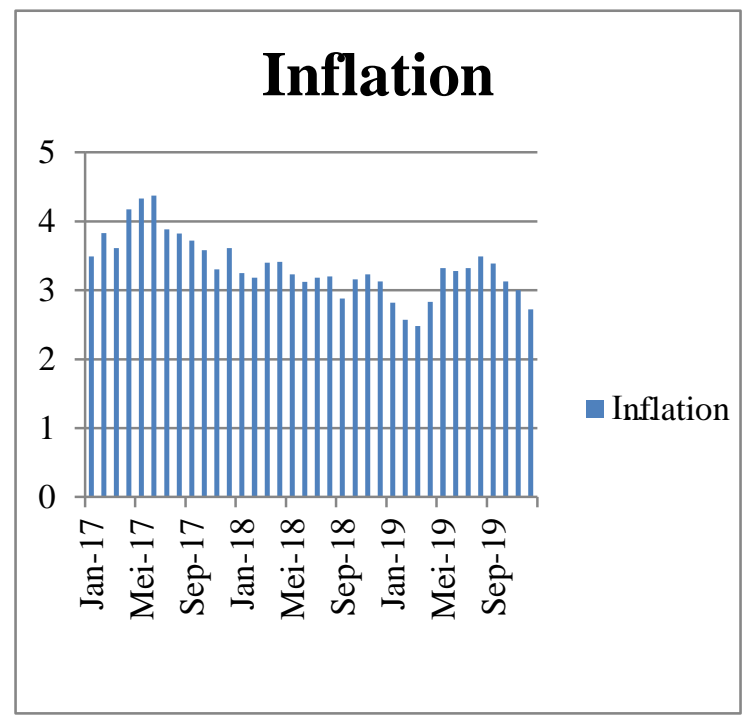

One measure of economic success can be measured from the rate of inflation that occurs. Thus, every country tries to do its best for the sake of improving the economy. For this reason, this study tries to see how much the impact of the interest rate variable and the money supply have at increasing inflation in Indonesia. The tendency of price level of goods and services generally and continuously can be seen by high and unstable inflation. With this increase of the price level, the purchasing power of the people will decrease as a result of which the products produced will not be sold out and the producers will not increase the amount of their investment. If the amount of 
investment is reduced, this will cause national income to decrease, which is a description of economic growth which will ultimately affect the stability of an economy's activities, namely as a wheel of development. The economic activities of a country are never separated from the activities of paying money. Money payment traffic refers to the money supply. If The amount of money changes will affect economic activity in many kinds of sectors. An excessive increase in the money amount can push price increases (high inflation) around the expected level so that in the long-term it can disrupt economic growth. When the money amount in a country is so low, it will create a low economic too. If this case keeps happening, the prosperity of society as a whole will decrease too. In consequence, to get a good management of money supply, considering the further influence can be an import thing to think about. (Langi, Masinabow \& Siwu, 2014).

The money supply used in this study is the change in the amount of money in a large sense (M2). The development of the Money Supply in Indonesia during 2017-2019 (research years) can be seen in Figure 2.

\section{Amount of Money} Supply (JUB)

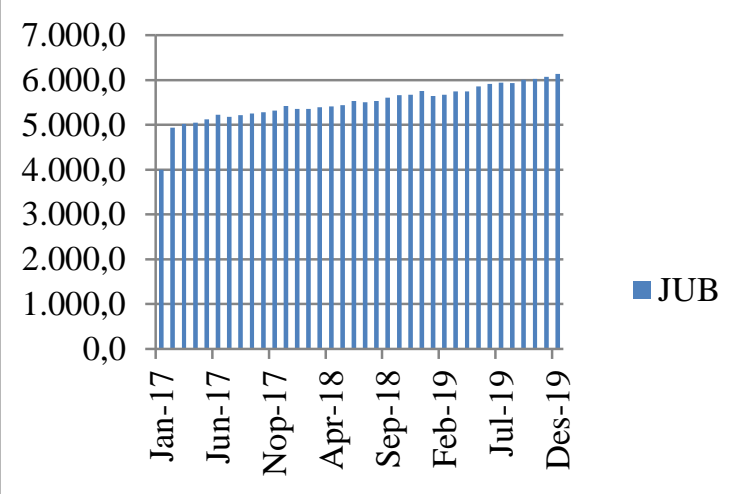

Figure 2. The Amount of Indonesian Money Supply 2017-2019

Source: Bank Indonesia research data (processed in 2020)
Although the quantity theory of money is a theory commonly used to describe the relationship between inflation and the money supply, there are theories that disagree and tend to oppose the quantity theory of money. The theory of opposition came from Keyseian and other non-monetary economists. They reject the orthodox interpretation of the quantity theory of money. Inflation in their theory focuses more on actual price increases, with or without consideration of the money supply. According to the Keynesian economist, inflation is divided into two, namely demand-pull inflation and costpush inflation. Demand-pull inflation occurs when the demand for goods is faster than the production of goods. In other words, inflation will occur when the demand for goods is greater than the available stock of goods. Cost-push inflation occurs when the input price for a good tends to rise. This can occur because the money supply is greater at a faster rate than consumer preferences change. Although based on the theory, it can be known that the increased money amount will increase inflation too, but there are some conditions of this theory is not true. Or in another word, we can say an increased money amount will not increase inflation too. If the increase of the money amount is faster than the growth in real output, then inflation will occur. The reason is that there is more money circulating, but the amount of goods stock in the market is fixed. Furthermore, the demand for goods will increase so that companies increase the price of goods. Beside that, if the increased money amount equals real output, price of goods will stay be same so as not to cause inflation.

Likewise with the interest rate variable. Inflation is often associated with other economic elements in macroeconomics. One of them is the interest rate. Interest is a cost that appears from the activity of lending money. When borrowing money, you will be charged a 'rental fee' for the money borrowed. You 
are required to pay 'rent' or 'interest' during the period of the loan until it is due for repayment.

Many factors determine the level of interest rates. Not only the debtor's credit score or rating, but also depending on supply or demand. When the level of demand for loans is high and the level of supply is low, the interest rate will also be high. Conversely, if the level of demand is low and the level of supply of loans is high, the interest rate will also be low. So what is the relationship between inflation and interest rates? The interest rate is applied to the loan. Therefore, interest rates have an important role in the banking industry. In general, the loan interest rate is determined by the central bank as the highest authority in the banking industry. However, each commercial bank in particular has the authority to determine the loan interest rate, but it cannot be more than the interest rate set by the central bank. The central bank has a set of policies capable of influencing the inflation rate in order to regulate price stability and economic growth. It is not surprising, because the central bank is the highest authority in determining monetary policy. For this authority, central Bank can also manipulate the short-term interest rate to influence inflation rate of an economy.

The interest rate used in this study is the BI interest rate or the BI Rate which is interest rate policy set by Bank Indonesia concerned with monetary policy that will be applied to the public in Indonesia. The developments in BI Interest Rates in Indonesia during 2017-2019 as the research year are as follows. During January 2017-July 2017 the interest rate was at $4.75 \%$ and decreased in August 2017 at $4.50 \%$ and the decline occurred again during September 2017-April 2018 at $4.25 \%$. A significant increase occurred during November 2018-June 2019 at $6.00 \%$ which then decreased in December 2019 at $5.00 \%$. It can be seen in Figure 3 below:

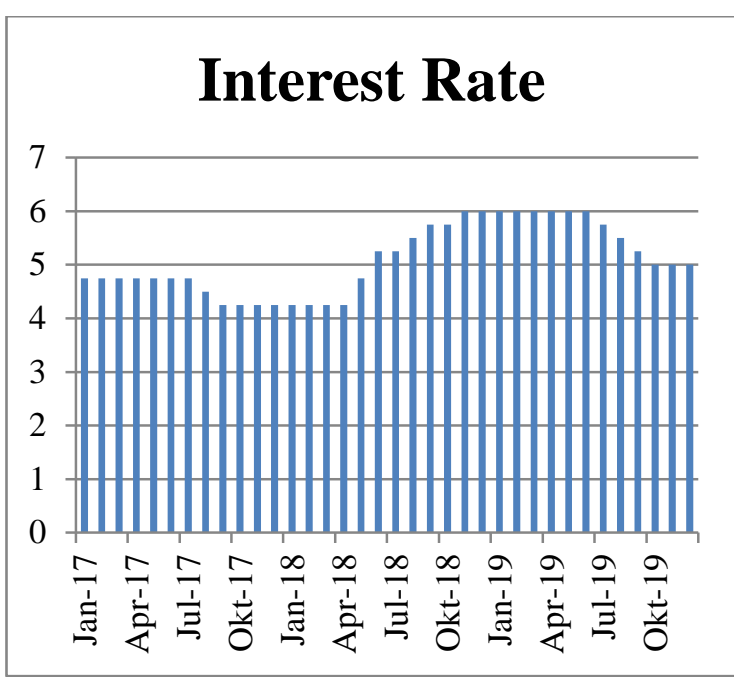

Figure 3. Indonesia's Interest Rate (BI Rate) in 2017-2019

Source: Bank Indonesia research data (processed in 2020)

Inflation and interest rates have an inverse correlation, where when inflation increases, interest rates will fall. Conversely, when interest rates fall or are low, there will be more demand for loans, where people will choose to borrow more money than save. This means that more money that will be spent, so that the economy grows and the inflation rate increases. Conversely, when interest rates increase, the demand for loans decreases, because people prefer to save because the rate of return from savings is higher. This will further impacted in less money being spent, resulting in a slowdown in the economy and lower inflation. More clearly, several things that affect inflation will be discussed in this study. So that this study can be useful in the future.

\section{LITERATURE REVIEW}

\section{Inflation}

There are many definitions of inflation within the scope of economics. In the early period, the definition of inflation that was often used after the second world war according to AP Lehner was a condition in which there was excess demand for goods in an economy as a whole (Gunawan, 1991). According to 
(Boediono,1995) inflation is defined as the tendency of prices to increase in general and take place continuously. Meanwhile, according to FW Paish provides an explanation of inflation as a condition in which national income increases much faster than the increase in goods and services produced in an economy (Gunawan, 1991). From the above understanding, First, tendency, in the form of a tendency for prices to increase, meaning that in a certain time it is possible for a price decrease to occur but overall it has an increasing tendency. Second, sustained, the price increase that occurs does not only last a certain time, but continuously over a long period of time. Third, general level of price, price in the context of inflation is intended as the price of goods in general, not only in the sense of one or two types of goods.

While, inflation kinds of its origins, which is more directed at external or internal factors, causing price goods will increase. When viewed by its origin, it could be divided into 2, namely: First, inflation that comes from within the country (domestic inflation). This inflation occurred due to pressure from domestic macro variables, which led to an increase in the prices of goods. Second, imported inflation. It is inflation that occurs due to influence from abroad (external factors). This effect can be in the form of inflation (price increases) in other countries that are closely related, so that the prices of imported goods become more expensive. This impact will directly cause the consumer price index to increase, and undirectly will increase consumer price index through the increased production fee

\section{Inflation Theory}

\section{Quantity Theory}

The basic concepts of quantity theory can be described as follows: First, Inflation can only occur if there is an increase in the money supply (additional currency or demand deposit) without being accompanied by a significant change in the amount of goods produced. Second, the rate of inflation is also determined by public expectations of rising prices for goods in the future (Boediono, 1995).

There are 3 (three) possibilities regarding public expectations regarding price increases. First: if the public does not expect prices to rise, then the increased amount of money will be accepted by the public to increase its liquidity. Second, if society, based on the experience of previous time periods, begins to become aware of inflation. Third, occurs when inflation is in a more severe condition, namely hyperinflation. In this situation the public has lost confidence in the currency, so the public expects worse conditions in the future.

\section{Keynes's Theory}

The Keynesian theory has a basic concept of Inflation .This is based on his macro theory. Inflation can happen because a society wants to live around the limits of its economic capacity (disposable income). This is translated into a condition where public demand for goods exceeds the number of goods available, so that an inflationary gap appears. This inflationary gap arises because people have succeeded in translating their aspirations into effective demand for goods. Inflation will continue as long as the amount of effective demand from society exceeds the amount of output that can be produced by society. Inflation will only stop if the total effective demand does not exceed the prevailing prices of the available output amount. In terms of the money supply, high growth is often being the cause of high inflation rates. If the amount of money increase it will cause an increase in the angregate demand too. When, these conditions are not balanced with growth in the real sector, prices will increase (inflation occurs). 


\section{Structuralist Theory}

The structuralist theory of inflation is according to experiences in Latin American countries. The structuralist theory emphasizes the inflexibilities of the economic structures of developing countries. Because inflation is associated with structural factors, so based on this theory. It can be known that developing country economies has 2 major rigors that can lead to inflation, namely (Boediono, 1995): First, the rigidity in the form of 'inelasticity' of export revenues, namely export value is growing slowly compared to other sectors. Second, rigidity is related to the inelasticity of the supply or production of domestic foodstuffs. Domestic food production growth has not been able to keep up with population growth and per capita income growth. As a result, the price of domestic foodstuffs tends to rise continuously, exceeding the increase in non-food goods. This condition will affect the demand side (demand), in the sense that the production fee, which also means an increase in the price of goods. The process will continue and also can be automatically stopped according to the reduction of the price of foodstuffs.

\section{BI Interest Rate}

Bank Indonesia is strengthening the monetary operation framework by implementing a new benchmark interest rate or policy interest rate, namely the BI 7-Day (Reverse) Repo Rate , which was applied effectively on 19 August 2016, replacing the BI Rate. This strengthening of the monetary operation framework is a common practice in various central banks and is an international best practice in the conduct of monetary operations. The monetary operations framework is continually being refined to strengthen policy effectiveness in achieving the set inflation target. The BI 7-day (Reverse) Repo Rate instrument is used as the new policy rate because it can quickly influence the money market, banking and real sectors. The BI 7-Day Repo Rate instrument as a new benchmark has a stronger relationship to money market interest rates,

With the use of the BI 7-day (Reverse) Repo Rate instrument as a new policy rate, three main impacts are expected. First, strengthening monetary policy signals with the 7-day (Reverse) Repo Rate as a main reference on the financial market. Second, the increased effectiveness of monetary policy transmission through its influence on movements in money market interest rates and bank interest rates. Third, the formation of a deeper financial market, particularly transactions and the formation of an interest rate structure on the interbank money market (PUAB) for a tenor of 3-12 months.

\section{The Impact of BI Interest Rate on Inflation}

One of the factors that influence changes in inflation in Indonesia is the benchmark interest rate of Indonesian banks or in other words the BI Rate, which is a signal for banks to set interest rates such as savings, deposits and credit. According to Yodiatmaja (2012:3) changes in the BI Rate will affect several macroeconomic variables which are then passed on to inflation. Changes in the form of an increase in the BI Rate are aimed at reducing the rate of economic activity that can trigger inflation. When the BI Rate rises, credit and deposit interest rates will also increase. When deposit rates rise, people will keep all of their money in banks, it causes the amount of money in circulation reduces. On credit interest rates, an increase in interest rates will move business actors to decrease their investment due to higher capital costs. This is what dampens economic activity and ultimately reduces inflationary pressure.

To overcome downturn economy. One of the way that Bank Indonesia can use is by doing expansionary monetary policy 
through lowering interest rates to stimulate economic activity. A reduction in the BI Rate will lower the rates, so that demand for credit from companies and households will increase. A reduction in loan interest rates will also reduce the cost of capital for companies to invest. All of these will increase consumption and investment activities so that economic activity will be more vibrant. Conversely, if the pressure of inflationary increases, Bank Indonesia responds by raising the BI Rate to put a brake on economic activity that is very fast to reduce inflationary pressure (Bank Indonesia, 2013). The monetary authority will raise interest rates to influence bank interest rates, namely the interest rates for savings, deposits and credit. An increase in the interest rates for savings and deposits will make a person or society tend to keep their money in the bank so that the money supply will decrease. Also an increase in credit interest rates will make the demand for credit from a person or company to decrease so that there is no more additional production capacity, thereby reducing inflationary pressure.

\section{Money Supply}

Money supply is the obligation of the monetary system (Central Bank, Commercial Bank and Rural Bank / BPR) to the domestic private sector (excluding the central government and non-residents). Liabilities that constitute a component of the Money Supply consist of currency held by the public (outside commercial and rural banks), demand deposits, quasi money held by the domestic private sector, and securities other than shares problems by the monetary system owned by the domestic private sector with the remaining period is up to a year. The amount of money can be defined in a narrow sense (M1) and in a broad sense (M2). M1 includes currency held by the public and demand deposits (current accounts denominated in Rupiah), while M2 includes M1, quasi money (includes savings, time deposits in rupiah and foreign currency, and demand deposits in foreign currency), and securities problem by the monetary system owned by the domestic private sector with the remaining period is up to a year.

Factors affecting the Money Supply are Net Foreign Assets (NFA) and Net Domestic Assets (NDA). Net Domestic Assets, consist of Net Claims on Central Government (NCG) and claims on other sectors (private sector, regional government, financial institutions and nonfinancial companies) especially in the form of given loans. Money supply is prepared by referring to the Monetary and Financial Statistics Manual (MFSM) 2000 and the Compilation Guide (2008).

\section{Impact of Money Supply on Inflation}

One of the ways the government has taken to increase the relatively high rate of economic growth from year to year is through the increasingly rapid development of the financial sector today. However, along with these monetary developments, combination between the money supply and economic growth and inflation tends to be less stable.

As a result, the monetary crisis hit developing countries and shattered their economic structure. Even for Indonesia, this has continued to an economic and political crisis that has caused significant damage to the joints of the national economy (Prayitno et al. 2002: 47).

An economy that is moved by the increasing money supply can cause goods prices will increase which tend to cause inflation. On the other hand, development requires a large expenditure of funds and it cannot be denied that the increasing development activities which are marked by the growth in state expenditure will cause inflationary pressure (Wahjuanto, 2010).

A sustained high growth rate of money supply will result in a high inflation 
rate and a low growth rate of money supply which in turn will result in a low inflation rate. Furthermore, the statement that inflation is a monetary phenomenon implies that the high inflation rate will not continue if it is not accompanied by a high rate of money supply growth (Dornbusch and Fischer, 1997: 589). From this, it could be concluded, there was a positive correlation between the money supply and inflation, where the increase of money supply will increase the inflation rate too. Otherwise the reduction of money supply will reduce the inflation rate too.

\section{RESEARCH METHODS}

\section{Location and Object of the Research}

The locations in this study are all regions of Indonesia using Bank Indonesia data (accessed through https://www. bi.go.id), which was related to inflation, interest rates and the amount of money supply for period from 2017-2019.

\section{Types, Data Sources and Data Collection Methods}

This research used the type of data, namely quantitative data, including data on the development of inflation, interest rates and the amount of money supply in Indonesia for period from 2017-2019. The data source was from data in the annual reports form and had been prepared and published by Bank Indonesia. Collecting data in this study using non-behavioral observation techniques, in which the researcher is an independent observer.

\section{Data Analysis Technique}

This study used data analysis techniques of multiple linear regression analysis, simultaneous testing with the $\mathrm{F}$ test, partial testing with the $\mathrm{t}$ test, testing the estimation model with classical assumptions.
The general form of the equation from multiple linear regression analysis is as follows:

$\mathrm{Y}=\alpha+\beta 1 \mathrm{X} 1+\beta 2 \mathrm{X} 2+\mu$

Information :

$\mathrm{Y}=$ Inflation rate in Indonesia period from 2017-2019

$\mathrm{X} 1=$ Interest rate in Indonesia period from 2017-2019

$\mathrm{X} 2=$ Amount of money supply in Indonesia period from 2017-2019

B1, $\beta 2=$ Regression Coefficient

$\mu=$ Nuisance Error

\section{RESULTS AND DISCUSSION}

\section{Descriptive Statistics}

Descriptive analysis is an analysis performed to assess the characteristics of data. There were 36 observations with a study period of 3 years. Within 3 years, the mean (average value) was 3,3452 with a minimum value of 2.4800 and a maximum value of 4.3700 and a standard deviation of 0.4390 .

\section{Multiple Linear Regression Analysis}

Multiple linear regression analysis is used to determine the effect of the independent variable, namely the interest rate (X1), the money supply (X2) on the dependent variable, namely inflation (Y). The regression results using the Eviews data processing program were then entered into the multiple regression equation as follows:

$Y=6.680706-0.230912-0.000393$

Based on the formula, it could be interpreted as follows: First, constant value 6.680706 this means that if $\mathrm{X} 1$ and $\mathrm{X} 2$ are equal to 0 then the inflation rate is equal to 6.680706. Second, if X1 increases by one unit, the inflation rate will decrease by 
0.230912 and otherwise if the value of $\mathrm{X} 1$ decreases by one unit, the inflation rate will increase by 0.230912 . Third, if X2 increases by one unit, the inflation rate will decrease by 0.000393 and otherwise if X2 decreases by one unit, the inflation rate will increase by 0.000393 .

\section{Simultaneous Significance Test (Test F)}

Based on the research results, it showed a P-Value of $0.000296<a$ then H0 was rejected or $\mathrm{H} 1$ was accepted, this meant that there was a significant impact of the variable interest rate and money supply simultaneously to the inflation rate in Indonesia in 2017 - 2019 with a confidence level of $95 \%(a=5 \%)$.

This supported the research conducted by Langi, Masinambow and Siwu, (2014) with the title Analysis of the Effect of BI Interest Rates, Money Supply and Exchange Rates on the Inflation Rate in Indonesia showed that simultaneously, there was a significant effect of changes in BI interest rates, money supply and the exchange rate had to inflation in Indonesia.

The $\mathrm{F}$ test results in this study were in line with previous research conducted by Suhesti Ningsih (2018) with the title Analysis of the Effect of Money Supply, Interest Rates and Exchange Rates on Inflation in Indonesia for period from 2014-2016 which stated that simultaneously there was a significant impact of variable of interest rates and the money supply to the variable of inflation rate in Indonesia.

This showed that variables of interest rates and money supply, if tested simultaneously or together, there was a significant impact to the inflation. Inflation as we know in Indonesia as a developing country is a long-term problem due to structural constraints in the country's economy. Correcting the inflation problem in Indonesia, if only carried out with shortterm monetary instruments, will not be sufficient to overcome the problem of inflation. What needs to be done is to improve the real sector in order to overcome inflation in Indonesia.

\section{Partial Significance Test (t test)}

\section{The Interest Rates Impact on Inflation}

$\mathrm{P}$ value $(0.02)<\alpha(0.05)$ indicated that $\mathrm{H} 0$ was rejected, this meant that the money supply variable (X2) had a significant impact and the regression coefficient value was negative $(-0.230912)$ showed that there was a negative impact of the interest rate to the inflation rate in Indonesia for period from 2017-2019 .

Both, inflation and interest rates have an inverse correlation, where when inflation increases, interest rates will fall. Otherwise, when interest rates fall or are low, there will be more demand for loans, where people will choose to borrow more money than save.

\section{The Effect of Money Supply on Inflation}

The $\mathrm{p}$ value $(0.03)<\alpha \quad(0.05)$ indicated that $\mathrm{H} 0$ was rejected, this meant that the interest rate variable (X1) had a significant effect and the regression coefficient value was negative $(-0.000393)$ showed that the money supply had a negative effect on the inflation rate in Indonesia for the 2017-2019 period.

The results of this study supported the research conducted by Putri (2017), the results showed that partially the money supply had a negative impact to inflation in Indonesia as well as research conducted by Putri (2017) with the title Analysis of the Effect of Money Supply, Interest Rate of Bank Indonesia Certificate (SBI) and Investment Credit Interest Rates on Inflation In Indonesia showed that partially, the money supply had a negative and significant impact to inflation in Indonesia, the interest rate of Bank Indonesia Certificate (SBI had a positive 
impact to inflation in Indonesia and the investment credit interest rate had a negative impact to inflation in Indonesia.

Results of this study were also in line with previous research conducted by Ningsih and Kristiyanti (2018) stated that the money supply variable partially had a negative and significant impact to the variable of inflation.

\section{Determinant Coefficient / Goodness of fit Test $\left(\mathbf{R}^{2}\right)$}

Based on the table above, it is known that the $\mathrm{R}^{2}$ squared value is 0.388 . This showed that the BI Interest Rate and the Money Supply variables are able to explain the inflation rate in Indonesia of 38.8 percent. And the remaining 61.2 percent is influenced by other variables not examined in this study.

\section{Classic Assumption Testing Normality Test}

In this study the method used for the normality test was the Jarque-Bera statistic where in Figure 1.The test results showed the Jarque-Bera statistical value, the result was that the probability value was $0.446010>0.05$, this meant that the residual data used was normally distributed and feasible to predict (Rawlings et al.1998).

\section{Multicollinearity Test}

A good regression model is a regression that does not have a strong correlation between the independent variables. From the table below, it could be explained that the estimation results of the correlation matrix value indicated that there was no multicollinearity problem. Because the Centered VIF value of both the interest rate and the money supply was $<10$, it could be stated that there is no multicollinearity problem (Ghozali, 2005).

\section{Autocorrelation Test}

Autocorrelation shows the correlation between members of a series of observations ordered according to time and space. To detect the presence or absence of autocorrelation in this, the Durbin-Watson test was performed.

Based on the estimation results, the calculated Durbin Watson (DW) value was 2.070777. Because $\mathrm{n}=36$ (many months) and $\mathrm{k}=2$ (number of independent variables) and comparing with the DW table, the dL value was 1.3537 and du was 1.5872. Because the dw value was between $\mathrm{du}$ and 4-du, it could be concluded that there was no autocorrelation problem in this study (Sugiyono, 2011).

\section{Heteroscedasticity Test}

Heteroscedasticity is a condition in which all disturbances that appear in the population regression function do not have the same variance. In this study using the Glejser method. From the results below, it was known that the parameter coefficient for each independent variable was insignificant (see the $\mathrm{t}$ test and the probability), so it could be concluded that there was no heteroscedasticity (Gujarati, 2012). 
Table 1. Descriptive Statistics Test Results

\begin{tabular}{lccc}
\hline & Inflation & Interest_Rate & Amount of Money Supply \\
\hline Mean & 3.345278 & 5.097222 & 5498.619 \\
Median & 3.290000 & 5.000000 & 5518.650 \\
Maximum & 4.370000 & 6.000000 & 6136.600 \\
Minimum & 2.480000 & 4.250000 & 4000.500 \\
Std. Dev. & 0.439074 & 0.660838 & 409.7358 \\
Skewness & 0.424048 & 0.145226 & -1.189466 \\
Kurtosis & 3.178325 & 1.583846 & 6.085370 \\
& & & \\
Jarque-Bera & 1.126598 & 3.134782 & 22.76824 \\
Probability & 0.569328 & 0.208589 & 0.000011 \\
& & & \\
Sum & 120.4300 & 183,5000 & 197950.3 \\
Sum Sq. Dev. & 6.747497 & 15.28472 & 5875919. \\
& & & \\
Observations & 36 & 36 & 36 \\
\hline
\end{tabular}

Source: Research data (processed in 2020)

Table 2. Regression Analysis Test Results

Dependent Variable: INFLATION

Method: Least Squares

Date: 07/30/20 Time: 18:37

Sample: 136

Included observations: 36

\begin{tabular}{lrlrc}
\hline \multicolumn{1}{c}{ Variable } & Coefficient & Std. Error & t-Statistic & Prob. \\
\hline \hline \multicolumn{1}{c}{ C } & 6.680706 & 0.805328 & 8.295631 & 0.0000 \\
INTREST_RATE & -0.230912 & 0.106308 & -2.172100 & 0.0371 \\
\multicolumn{1}{c}{ JUB } & -0.000393 & 0.000171 & -2.289420 & 0.0286 \\
\hline \hline & & & & \\
R-squared & 0.388880 & Mean dependent var & 3.345278 \\
Adjusted R-squared & 0.351842 & S.D. dependent var & 0.439074 \\
S.E. of regression & 0.353490 & Akaike info criterion & 0.837735 \\
Sum squared resid & 4.123532 & Schwarz criterion & 0.969695 \\
Log likelihood & -12.07923 & Hannan-Quinn criter. & 0.883792 \\
F-statistic & 10.49960 & Durbin-Watson stat & 2.070777 \\
Prob(F-statistic) & 0.000296 & & & \\
\hline
\end{tabular}

Source: Research data (processed in 2020) 


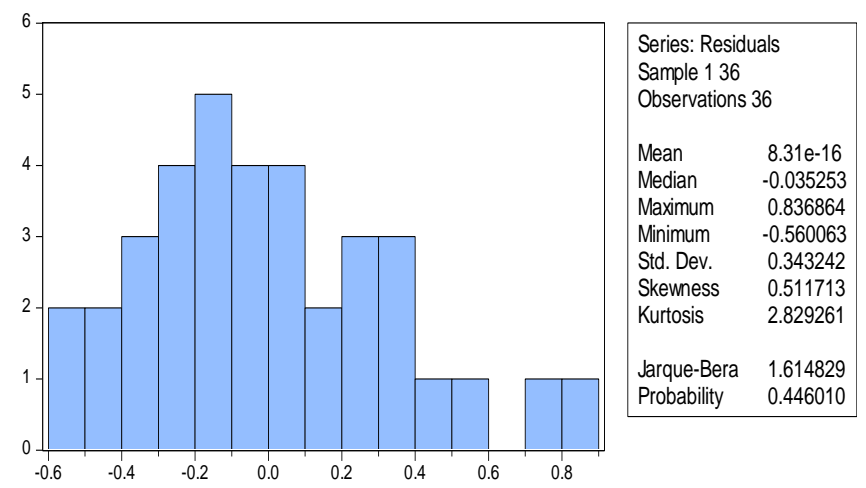

Figure 4. Residual Normality Test Results

Source: Research data (processed in 2020)

Table 3. Multicollinearity Test Results

Variance Inflation Factors

Date: 08/14/20 Time: 18:09

Sample: 136

Included observations: 36

\begin{tabular}{cccc}
\hline \hline Variable & $\begin{array}{c}\text { Coefficient } \\
\text { Variance }\end{array}$ & $\begin{array}{c}\text { Uncentered } \\
\text { VIF }\end{array}$ & $\begin{array}{c}\text { Centered } \\
\text { VIF }\end{array}$ \\
\hline \hline C & 0.648553 & 186.8499 & \\
INTREST_RATE & 0.011301 & 85.97768 & 1.382401 \\
AMOUNT OF MONEY SUPPLY & $2.940-08$ & & 1.382401 \\
\hline \hline
\end{tabular}

Source: Research data (processed in 2020)

Table 4. Heteroscedasticity Test Results

Dependent Variable: RESABS

Method: Least Squares

Date: 07/30/20 Time: 19:38

Sample: 136

Included observations: 36

\begin{tabular}{lrlrr}
\hline \hline \multicolumn{1}{c}{ Variable } & Coefficient & \multicolumn{1}{c}{ Std. Error } & t-Statistic & Prob. \\
\hline \hline \multicolumn{1}{c}{ C } & 0.825254 & 0.455734 & 1.810824 & 0.0793 \\
\multicolumn{1}{c}{ INTREST_RATE } & 0.057925 & 0.060159 & 0.962864 & 0.3426 \\
\multicolumn{1}{c}{-0.000154} & $9.70 \mathrm{E}-05$ & -1.586795 & 0.1221 \\
\hline \hline R-squared & 0.071486 & Mean dependent var & 0.273929 \\
Adjusted R-squared & 0.015213 & S.D. dependent var & 0.201579 \\
S.E. of regression & 0.200040 & Akaike info criterion & -0.300948 \\
Sum squared resid & 1.320522 & Schwarz criterion & -0.168988 \\
Log likelihood & 8.417062 & Hannan-Quinn criter. & -0.254890 \\
F-statistic & 1.270335 & Durbin-Watson stat & \\
Prob(F-statistic) & 0.294108 & & \\
\hline \hline
\end{tabular}

Source: Research data (processed in 2020) 


\section{CONCLUSION}

This study aims to obtain empirical evidence about the impact of interest rates and the money supply both partially and simultaneously on inflation in Indonesia for the 2017-2019 period. Based on the results of the analysis, it could be concluded that interest rates and the amount of money have an impact on inflation with a significance value of 0 , 000296. Meanwhile, the t-test results indicate that interest rates and the money supply have an impact on inflation, respectively, with values of significance are 0.0371 and 0.0286 . Referring to the results of the study, the government should be more wise inadjusting monetary policy related to interest rates and the money supply that can affect inflation. What needs to be done is to improve the real sector in order to overcome inflation in Indonesia. And for researchers who want to do reasearch with the same topic, it is better to add another relevant variable with inflation by using more variable and longer period and compare inflation rate in the developing country and advanced country.

\section{REFERENCES}

Bank Indonesia. (2020). Money Supply Development. Retrieved from http://www.bi.go.id/id/publikasi/ perkembangan/Default.aspx

Bank Indonesia. (2020). Inflation. Retrieved from https://www.bi.go.id/ $\mathrm{id} /$ moneter/inflasi/data/Default.aspx.

Bank Indonesia. (2020) BI 7-Day Repo Rate. Retrieved from http://www. bi.go.id/moneter/bi-7day-RR/data/ Contents/ Default.aspx.

Boediono. (1995). Pengantar Ilmu Ekonomi Makro.Yogyakarta: BPFE.

Dornbusch, R., \& Fisher, S. (1998). Macroeconomics: Fourth Edittion. Singapore: McGraw-Hill Publications. Ghozali, I. (2005). Aplikasi Analisis Multivariate dengan Program SPSS. Semarang: Badan Penerbit UNDIP.
Gujarati. (2012). Dasar-dasar Ekonometrika: Edisi 5. Jakarta: Salemba Empat.

Langi, T. M., Masinabow,V., \& Siwu, H.(2014). Analysis of the Effect of BI Interest Rates, Money Supply, and Exchange Rate on Inflation Rate in Indonesia. Jurnal Berkala Ilmiah Efisiensi, 14 (2), 44-58.

Ningsih, S., \& Kristiyanti, L. M. S. (2018). Analysis Of Amount Of Money Supply, Interest Rate And Exchange Rate Influence on Inflation In Indonesia 2014-2016 Period. Jurnal Manajemen Dayasaing, 20(2), 96103.

Perlambang, H. (2010). Analysis of the Effect of Money Supply, Interest Rates of Bank Indonesia Certificate, Exchange Rates on the Inflation Rate. Media Ekonomi, 19 (2), 1-19.

Perlambang, H. (2017). Analysis of The Money Supply, Interest Rates of Bank Indonesia Certificate (SBI), The Exchange Rate Influence on The Inflation Rate. Media Ekonomi, 18(2), 49-68.

Prayitno, L., Sandjaya, H., \& Llewelyn, R. (2012). Faktor-Faktor Yang Berpengaruh Terhadap Jumlah Uang Beredar di Indonesia Sebelum dan Sesudah Krisis: Sebuah Analisis Ekonometrika. Jurnal Manajemen \& Kewirausahaan, 4(1), 46-55.

Putri, V. K. (2017). Influence Analysis of Money Supply, Interest Rates of Bank Indonesia Certificate and Investment Credit Interest on Inflation In Indonesia. JOM Fekon, 4(1), 26-39.

Rawlings, J.O. (1998). Applied Regression Analysis. California: Brooks/Cole Publishing.

Sugiyono. (2011). Metode Penelitian Kuantitatif, Kualitatif dan $R \& D$, Cetakan ke-14. Bandung: Alfabeta.

Sutawijaya, A. (2012). Influence of Economy Factors on Inflation in Indonesia. Jurnal Organisasi dan Manajemen, 8(2), 85-101. 
Swandayani, D. M., \& Kusumaningtias, R. (2012). The Effect of Inflation, Interest Rates, Foreign Exchange Rates and The Money Supply on Profitability in Islamic Banking in Indonesia for period of 2005-2009. AKRUAL: Jurnal Akuntansi, 3(2), 147-166.

Wahjuanto, M. (2010). Beberapa Faktor Yang Mempengaruhi Inflasi. Skripsi. Universitas Pembangunan Nasional Veteran Jawa Timur.

Yonoatmaja, B. (2012). Hubungan Antara BI Rate dan Inflasi Pendekatan Kausalitas Toda-Yamamoto. JEJAK, 5(2), 117-229. 